Viktoriia Maikovska, $\mathrm{PhD}$ (Pedagogy), Kharkiv Trade and Economics Institute of Kyiv National University of Trade and Economics, 8, O. Yarosh lane, Kharkiv, 61045, Ukraine, ORCID: 0000-0001-8165-0395;

ResearcherID: O-7460-2016

Olena Semenog, Doctor of Sciences (Pedagogy), Professor, A.S. Makarenko Sumy State Pedagogical University, 87, Romenska Street, Sumy, 40002, Ukraine, ORCID: 0000-0002-8697-8602; ResearcherID: E-2994

\title{
REQUIREMENTS ANALYSIS CONCERNING ENTREPRENEURIAL COMPETENCE OF FUTURE SPECIALISTS IN TOURISM IN THE CONTEXT OF NATIONAL EDUCATIONAL TRANSFORMATIONS
}

The article deals with theoretical aspects and practical results of finding the grounds for choosing directions for the entrepreneurial competence formation. It is established that the professional training of modern tourism specialists should be carried out in moral and ethical, professional and business, communicative directions. It has been made the analysis of the level of formation of the moral and ethical block of the tourism specialist' personality, the level of his professional-business and communicative training; the reasons for students' unpreparedness for active entrepreneurship have been identified. The results of the ranking of educational disciplines and didactic tools that provide the level of entrepreneurial competence formation of future tourism specialists are presented.

Keywords: entrepreneurship, entrepreneurial competence, professional education, professional training, vocational training.

Relevance of research topic. The national economy integration into the world economic space necessitates the availability of that specialists' competencies that will allow them to adapt to modern socio-economic conditions quickly, to respond flexibly to the demands of society and to work effectively in a market economy terms. At the same time, traditional management systems, which are still characteristic for national market participants, have proved as outdated and inefficient. Numerous factors in the context of competition (such as the need to attract resources from a variety of sources, 
the introduction of an innovative style of economic behavior, the manifestation of autonomy and initiative) were considered as insignificant and ignored until now; but nowadays they have started to influence significantly the production and economic activity of market participants. In terms of market relations, the development of the national market of services and the increase of employment of the population in the country are largely influenced by entrepreneurial activity in the service sector. Despite the fact that the service sector is one of the priority sectors of the Ukrainian economy, the financial and economic status of service providers - the representatives of small and medium-sized businesses has a tendency to deteriorate and requires a persistent search for tools for entrepreneurship and business activity' development.

Formulation of the problem. The results of the analysis of scientific sources and practical experience suggest that: the problematic aspects of the entrepreneurial activity development in the market of services are: the mismatch between the public need for high-quality services in the sphere of tourism business and their existing national level; the public need for service professionals capable of working effectively as business entities. Obviously, this problem in the conditions of aggravation of competition in the markets of educational services and labor is urgent.

\section{Analysis of recent researches and publications.}

The main conceptions which determine the directions of the service sector development in general and the tourism industry in particular, specified in the Law of Ukraine «On Tourism» [2], the Concept of the State Target Program for the Development of Tourism and Resorts for the period up to 2022 [3], the Tourism and Resort Development Strategies for 2026 [8], as well as some regional documents: the Lviv Tourism Industry Development Program for 2016-2022 [6], the Strategies for Activation of the Dnipro Tourism Potential [7], etc. These documents accent attention on the lack of knowledge and business skills and emphasize that tourism is a priority sector of the Ukrainian economy [2], which provides job creation [3] and is a factor of employment based on self-employment [8]. The Tourism and Resorts Development Strategy for 2026 directly emphasizes the problem of encouraging young people to be active, develop innovative products and start a business in this field.

In the last decade, various aspects of the competent tourism specialist training have been studied in pedagogical science: the problems of forming their communicative, general cultural and technological competence during professional training, including with the use of interactive technologies (O. Nesterova, M. Chorna, M. Didukh, K. Kozubenko); the formation of professional competence by means of information and communication technologies (G. Loic); the formation of key competences during the humanities courses studying (N. Bondar); professional culture formation by tools of multimedia technologies (M. Akentyeva, O. Netrebina); information and legal culture formation in the process of professional training (T. Zubekhina, V. Dymochkina). The subjects of the research were: training specialists in tourism by using recreational resources of the Carpathian region (O. Boychak); 
professional training of tourism managers for management activities (G. Stolar); their foreign language training in higher education institutions (N. Ivasiv); formation of their readiness for professional interaction with tourist services consumers (O. Dyshko), formation of their readiness for professional self-realization (M. Karpovich, T. Kolesnik), formation of their readiness for excursion activity (S. Litovka), preparation for realization of investment projects in professional activity (L. Gerasimchuk), preparation for a professional activity in the field of social tourism (D. Lyuta). Detailed attention was paid to theoretical and methodological principles of professional training of future specialists in tourism in the field of adaptive tourism (A. Kukhtiy), preparation to tourist and recreational activities (L. Malyk) and to the system of cross-cultural training of future specialists in the tourism industry (V. Sidorov). Special attention should be paid to the study of the features of professional training of future tourism specialists in educational establishments of the USA and Canada (S. Babushko, N. Zhornyak); professional schools of Turkey (M. Malysheva); higher education institutions in New Zealand and Mexico (L. Ermak, L. Balahadze); the universities of France (O. Palamarchuk). Unfortunately, the results of the scientific search did not allow us to find publications that would raise the issues of service sector requirements to the level of entrepreneurial competence of future tourism specialists in the context of national educational transformations.

Presenting main material. The analysis of the papers of the above-mentioned researchers revealed the characteristic for the Ukrainian sphere of servicing a inconsistency between the public need for world-class tourism business services and the real national level of their providing; the objective need of society for professionals capable of working effectively as business entities and the lack of research on methodological approaches to improving their professional training process; the increase of professional interest of specialists in their own entrepreneurial competence and insufficient validity of conceptual bases of its formation in the process of professional training. This inconsistency overcoming requires a rethinking of conceptual and methodological approaches to the professional training of future specialists. Therefore, vocational training in the specialty 242 «Tourism», which is now dominated by the traditional approach, should be regarded as a general pedagogical phenomenon with appropriately updated components - purpose, structure, and content. In this case, entrepreneurial competence formation should include gaining entrepreneurial knowledge, the development of entrepreneurial qualities, the formation of entrepreneurial behavior and creation of entrepreneurial culture descriptors.

Vocational training Modernization in order to form entrepreneurial competence within each specific educational institution requires careful preliminary analytical work: 1) studying the psychological qualities of students' personality; 2) identification of directions of work on preparation for business activity; 3) activity programs development; 4) educational content selection; 5) identifying the forms, methods, and tools that can ensure success. 
In order to solve these problems, in the process of our study, the leading areas of purposeful activity were identified. The bases for the expert evaluation were two fundamental points - relevance (highlighting the characteristics that are most significant for the modern entrepreneur) and attainment (the possibility for students to acquire these characteristics within the educational process). As a result of the experts' assessment processing, three blocks of characteristics with the highest ranks were identified: moral and ethical (as one block), business and communicative. It helped us create the base for updating the areas of professional training: moral and ethical, professional and business, and communicative.

The level of formation of the moral-ethical block of the tourism specialist's personality was estimated by the method of diagnostics of social-psychological settings in the motivational-needy sphere (by using the test of A. Potemkina) [1]. The results of the analysis allowed to state that $67,1 \%$ of students were altruistic oriented along the line «altruism - selfishness»; $16,4 \%$ - for selfishness; the other $16,5 \%$ did not show a clear orientation. A comparison of students' attitudes on the line «process result» eloquently indicated the orientation of the majority of students $(83,2 \%)$ on the result. Determining student attitudes along the line «freedom - power» allowed us to state $100 \%$ of students' focus on freedom. Assessment of students' motivation on the line «work - money» did not give an unambiguous orientation: $33,5 \%$ were oriented to work; $15,9 \%$ - for money; the other $50,6 \%$ did not show a clear orientation. In general, we can talk that future tourism specialists potentially have traits of entrepreneurs with the very low motivation of mercantile intentions.

The level of communication preparation was revealed by the students' selfestimation of their presentation skills. The study showed that these skills grow from junior to senior years. $50,6 \%$ of freshmen and $71,4 \%$ of elder undergraduates consider themselves capable of provoking in the audience interest in their own words and actions; $48,5 \%$ of freshmen and $85,7 \%$ of elder undergraduates consider themselves capable to use non-verbal means effectively.

The level of professional and business training was determined by the results of students' self-assessment and by using a questionnaire of their teachers. Analysis of students' self-esteem results showed that $91,1 \%$ of future tourism specialists consider entrepreneurial competence as an important component of professional competence, and $79,8 \%$ feel a clearly formed need to gain entrepreneurial experience during the learning process. The results of the teachers survey show that $100 \%$ of the respondents consider students to be ready for independent professional activity after graduation, but $83,4 \%$ of the teachers consider new specialists to be unprepared for independent entrepreneurial activity. The rating of the reasons for such unpreparedness is as follows:

- extra theorization of knowledge during the learning process $-100 \%$;

- lack of practical readiness of teachers for preparing students for entrepreneurship - 83,1\%; 
- weak correlation between the theoretical and practical components of the training or its absence $-68,1 \%$;

- lack of practical component of preparing students for entrepreneurship $67,3 \%$;

- lack of communication between students and entrepreneurs during the educational process $-66,7 \%$;

- absence in the educational process of analysis of real business problems and creating the ways of their solution $-65,9 \%$;

- absence of a holistic interdisciplinary picture of preparing students for entrepreneurship - 33,8\%;

- lack of professional readiness of teachers for preparing students for entrepreneurship - 16,4\%;

- lack of readiness of teachers to use forms and methods of interactive interaction in the educational process $-15,2 \%$.

At the same time, $83,4 \%$ of teachers emphasize the primary need for the student's personality development through entrepreneurship, 50,9\% consider providing students with knowledge as the main goal of the educational process, and $49,1 \%$ consider the organization of effective practical training for entrepreneurship as the main goal of the educational process. The opinion of the students in this regard is somewhat different: $70,4 \%$ believe that entrepreneurial competence can be formed in different classes; $65,1 \%$ think that entrepreneurial competence can be formed through participation in competitions, championships, and other business-themed events.

Also, students and teachers have different thoughts about the rating of courses and disciplines that provide entrepreneurial competence formation. For example, $94,7 \%$ of students and only $48,3 \%$ of teachers consider «The marketing» as compulsory for entrepreneurial competence development. Such classes as «The basics of entrepreneurship» (91,3\%), «The tourism economics» $(85,0 \%)$, and «The management» $(85,1 \%)$ have the biggest value among students. Teachers mostly choose «The basics of entrepreneurship» (51,9\%), «The information systems and technologies» $(49,8 \%)$, «The management» (48,3\%). Both sides emphasize the important role of the discipline named «The accounting». Teachers have a tendency to consider as the most valuable in the curriculum the disciplines with a purely pragmatic direction («The business law» and «The business planning»). At the same time for students, it is the list of disciplines that provide their professional and personal development («The fundamentals of leadership» and «The discipline and ethics of the entrepreneur»). Among the didactic tools, the use of which provides the level of entrepreneurial competence of future tourism specialists are contextual education, training, workshop and project method. 
As a result, agreeing with V. Lozovetska and others, we state the following. Each specific educational institution should create conditions for gaining by the future tourism specialists six types of experience: 1) cognitive; 2) experience of effective practical activity; 3) experience of social interaction; 4) moral and ethical experience; 5) spiritual and ecological experience; 6) the experience of reflecting consciousness [4]. The solution to this problem requires the introduction of specific forms of interaction between teachers and students into vocational training [5].

Conclusion. Summarizing the study results, we conclude that the preparation of young people for entrepreneurship should be carried out in the context of professional training and requires the use of appropriate methods. The level of entrepreneurial competence formation of future tourism specialists depends on the forms and methods which are used during vocational training. This makes it possible to create appropriate organizational, scientific, methodological and socio-psychological conditions for professional preparation. The factors that ensure the effectiveness of the entrepreneurial competence formation are optimization of the content of vocational education on an entrepreneurial background; implementation of the world experience of using modern technologies and methods of students' preparation for entrepreneurship; professional and psychological-pedagogical training of teachers in this field. Achieving the level of entrepreneurial competence formation implies a significant change in both the substantive and procedural component of the educational process: the forms of organization of students' educational activities should correspond to the forms of their future professional and social activity.

Definitely, it is impossible to cover all of the aspects of the above-mentioned issue in the paper. So, further scientific explorations will be linked with the development of a system of indicators of future tourism specialist's entrepreneurial competence and the criteria for their evaluation.

\section{REFERENCES}

1. Belkova, V. (2015). Kompetentsii sovremennogo predprinimatelya - osnova obrazovatelnogo protsessa studentov sistemy SPO (na primere Tomskogo industrialnogo tekhnikuma) [The Competencies of a Modern Entrepreneur - the Basis of the Educational Process of Students of the Act System (On the Example of the Tomsk Industrial College)]. Professionalnoe obrazovanie v Rossii i za rubezhom, Vol. 3 (19), pp. 120-125. Retrieved from: https://cyberleninka.ru/article/n/kompetentsiisovremennogo-predprinimatelya-osnova-obrazovatelnogo-protsessa-studentov-sistemyspo-na-primere-tomskogo-industrialnogo/viewe. pdf [Russian] 
2. Zakon Ukrainy «Pro turyzm» [The Law of Ukraine «On Tourism»]. Kyiv, 2004. Retrieved from https://zakon.rada.gov.ua/laws/show/1282-15/.pdf [Ukrainian]

3. Kontseptsiia Derzhavnoi tsilovoi prohramy rozvytku turyzmu ta kurortiv na period do 2022 roku [The Concept of the State Target Program for the Development of Tourism and Resorts for the Period up to 2022]. Kyiv, 2013. Retrieved from https://zakon.rada.gov.ua/laws/show/638-2013-p. pdf [Ukrainian]

4. Lozovetska, V. T. (vidp. $\quad$ red.). (2010). Formuvannia profesiinoi kompetentnosti fakhivtsia sfery posluh i turyzmu [The formation of services and tourism specialist' professional competence]. Kyiv, $382 \mathrm{~s}$. [Ukrainian]

5. Maikovska, V. I. (2017). Orhanizatsiia praktychnoi pidhotovky maibutnikh fakhivtsiv na zasadakh kontekstnoho pidkhodu [Organization of Future Specialists Practical Training on the Basis of the Contextual Approach]. Liudynoznavchi studii: zbirnyk naukovykh prats Drohobytskoho derzhavnoho pedahohichnoho universytetu imeni Ivana Franka, Vol. 4 (36), pp. 156-165. [Ukrainian]

6. Prohrama rozvytku turystychnoi haluzi $\mathrm{m}$. Lvova na 2016-2022 roky [The Lviv Tourism Industry Development Program for 2016-2022]. Lviv, 2016. Retrieved from https://www8.city adm.lviv.ua/inteam/uhvaly.nsf/(SearchForWeb)/0D 1D528CFBA5349AC2257F5400535D89?OpenDocument. pdf [Ukrainian]

7. Stratehiia aktyvizatsii turystychnoho potentsialu m. Dnipra [The Strategies for Activation of the Dnipro Tourism Potential]. Dnipro, 2017. Retrieved from http://dda.dp.ua/wp-content/uploads/2017/12/17_27.pdf [Ukrainian]

8. Stratehiia rozvytku turyzmu ta kurortiv na period do 2026 roku [The Tourism and Resort Development Strategies for 2026]. Kyiv, 2017. Retrieved from https://zakon.rada.gov.ua/laws/show/168-2017-p. pdf [Ukrainian] 